\title{
PRINCIPLES OF WORKPLACE DEMOCRACY: CASES FROM THE CZECH REPUBLIC
}

\author{
Andy VOPALECKÝ ${ }^{4}$ \\ University of Business and Law \\ Lukáš DURDA ${ }^{5}$ \\ Paneuropean University
}

\begin{abstract}
The article is about the concept of management of democratic companies in the Czech Republic with a focus on the principles of workplace democracy. The analysis is based on four case studies of democratic companies. The case studies have been drawn up on the basis of a questionnaire survey among the workers of companies and interviews with their executives. The research has shown the importance of even a high rate of implementation of the various principles in all surveyed companies. The best rated principle is "dialogue and listening". In the case of the principle of "reflection and assessment", it will show certain deficiencies in the provision of feedback. Principles of workplace democracy identified in interviews mostly agree with the principles referred to in the literature. Resulting from the research, it proposes recommendations and suggestions for further research.
\end{abstract}

\section{KEY WORDS}

democratic company, workplace democracy, freedom-based principles, management

\section{JEL CLASSIFICATION}

L26, M10

\section{INTRODUCTION}

In the 20th century many authors have considered that the bureaucratic organizations are technically capable of achieving the highest productivity and they have thought that they are the best possible solution for a fast developing world. Many theorists, however, have referred to the negative consequences of bureaucratic controlled organization which are as follows; frequent conflicts between employees and management, stopping production, illegal strikes, or even the violent

\footnotetext{
${ }^{4}$ Correspondence address: Andy Vopalecký, Ing., MBA; andy.vopalecky@ gmail.com, University of Business and Law, Vltavská 585/14, 15000 Praha 5, Czech Republic, http://www.vspp.cz

${ }^{5}$ Correspondence address: Lukáš Durda, PhDr.; lukas.durda@centrum.cz, Institute of Management and Marketing, Faculty of Economics and Business, Paneuropean University, Tomášikova 20, 82102 Bratislava, Slovak Republic, http://www.paneurouni.com
} 
clashes (Carney, Getz, 2013: 43). The area of technology, geopolitics and lifestyle has over the last fifty years changed fundamentally; however, the management has changed just a little. These slight changes, however, are not able to keep up with the speed of innovation and other global changes (Hamel, Breen, 2008: 17-18). Slinták (2015) stresses the need to change the philosophy of management based on a culture of "how" to a management philosophy based on a culture of "why". An organization should choose a new direction, which will be different from that of the earlier, which also requires a new look at the known issues (Handy, 2015), it should learn new ways of thinking and acting, in order to be able to adapt to changing conditions (Senge, 2006). Senge's concept of the learning organization is one of the approaches that is defined against traditional authoritative "checking" organizations. Senge emphasizes the transition to management based on the five disciplines (personal mastery, mental models, shared visions, team learning and systems thinking). Laloux (2014) also focuses on the values, practices and structures of the organization. Laloux comes with the concept of the so-called teal organisations that should be built on a shared sense of values, intrinsic motivation and self-management. Another hot concept is holacracy. Main structure of holacracy is an organization in circles, not in a hierarchy tree (Robertson, 2015). The concept of holacracy has gained great attention in management magazines, often in the context of the transformation of the company Zappos towards holacracy (e.g. Useem, 2015, Bernstein et al., 2016, Reingold, 2016). Some authors see to build to the concept of holacracy more sceptically. Birkinshaw (2014) points out that holacracy is one of a series of concepts that appear behind the highly acclaimed, but firms would be treated with these concepts very carefully. Their contribution can only be used if the company thoroughly consider the possibility of the introduction of the popular consultancy models and approaches. Pfeffer (2013) argues against efforts to create new management theory (particularly of power and influence), based on the belief that companies must start to work in a different way (to be more global, more dynamic, more innovative, less formal and hierarchical, more highlighting the teams and teamwork). In his opinion, the current theory can cover and describe ongoing changes.

The aim of the article is to analyse the application of the management principles of the democratic companies, and the perception of the importance of these principles from the perspective of the management of the company and from the perspective of employees. Even though the literature, appearing in management functioning of democratic organizations, descriptions are not yet implemented researches attesting to the applying placed principles. Attention is focused more on minor aspects, for example increasing the autonomy and self-control in companies, in particular self-managed teams (e.g. Proenca, 2010). There are studies focusing on the area of the social-moral climate in democratic companies (Weber et al., 2009, Verdorfer, Weber, 2016), but the contribution and effectiveness of the management of the democratic companies have not yet been explored more deeply. Researches in Germany have demonstrated the interest of the employees on the implementation of the principles of the democratic companies, at the same time, however, the big perception difficulties implementing these principles for managers (Boes et al., 2015). In the Czech Republic's efforts to popularize the topic appears democratic companies in the specialized press (for example Kejhová, 2015) and there is issued known publications to promote freedom at work (e.g. Semler, 2011, Hsieh, 2013), but researchers and academics do not pay too much attention to the democratic companies.

\section{LITERATURE REVIEW}

The concept of the democratic companies can be found in the literature also under other terms such as "democracy at work" (Ducasse, 2016; Fenton, 2006, 2012), "democratic enterprise" (Gratton, 2004), "post-bureaucratic organization" (Maravelias, 2007), "organizational democracy" (Yazdani, 2010), "F-Form companies" (Getz, 2009), ,an organization without a leader" (Brafman, Beckstrom, 
2006) or "labor-cooperative company" (Ducasse, 2016). The authors use these concepts in different contexts and individual concepts are intertwined. In the Czech Republic, there is relatively few resources on the topic of management, but the most frequently appearing terms "freedom at work" and "freedom-based company" (Carney, Getz, 2013). The above stated terminology does not consider companies managed in the traditional way as undemocratic or non-free in the legal concept. This is the concept of the management and functioning of the organization, based and emphases on certain aspects or principles. For example the democratic organization is emphasized by the concept of empowering all members of the organization (McAuley et al., 2006).

Among the examples cited of firms often based on the new concept of management include the aforementioned Zappos (Hsieh, 2013), Semco (detailed in Semler, 2011), FAVI (e.g. Laloux, 2014, Carney, Getz, 2013), and W. L. Gore \& Associates (e.g. Slinták, Tučková, 2016). In the Czech Republic is the most frequently cited free company is Etnetera (Kejhová, 2015).

Democratic companies are characterized by certain principles, characteristics or values, and differ from other firms. The authors present different concepts and principles of the democratic companies. Their comparison is shown in the following Table 1. If a principle cannot be compared with any other, is listed on a line, by itself.

Fenton (2012), Petersen (2012) and partially Hamel (2013) render principles of freedom-based company in a structured manner and in a coherent list. The other authors have mentioned the principles in a flat structure, rather as part of their works and it has been necessary to prepared that from their works. Petersen (2012) is based on Hamel's conclusions (Hamel, Breen, 2008), which speak of the so-called Management 2.0, which according to Hamel's conclusions about a new management for the 21st century. Hamel and Breen (2008) do not call these principles as principles of freedom-based company, but rather as principles or areas that is necessary to apply for the success of companies at this time. For example, adaptability and flexibility is an important value for the companies that want to thrive in today's world. Petersen (2012) states the basic twelve principles and the principles of money and capital, ownership, and the terminology lists as accidental, but there are also useful to cite. Ducasse (2016), in his article, underlines in particular the ownership of company by employees, which in turn has an impact on other principles. For example, if an individual owns something, then he or she also accepts responsibility and should also have the right to make decisions. Viggain (2011) indicates an example of a company in which they tried to apply the formula of effective democracy: Efficient democracy $=$ trust + delegation + accountability. Viggain (2011) also mentions that for the company, there are important the high performance teams and the ability to be an organization that continuously learns, which is related to the Hamel's adaptability and flexibility.

Table 1 Principles of workplace democracy

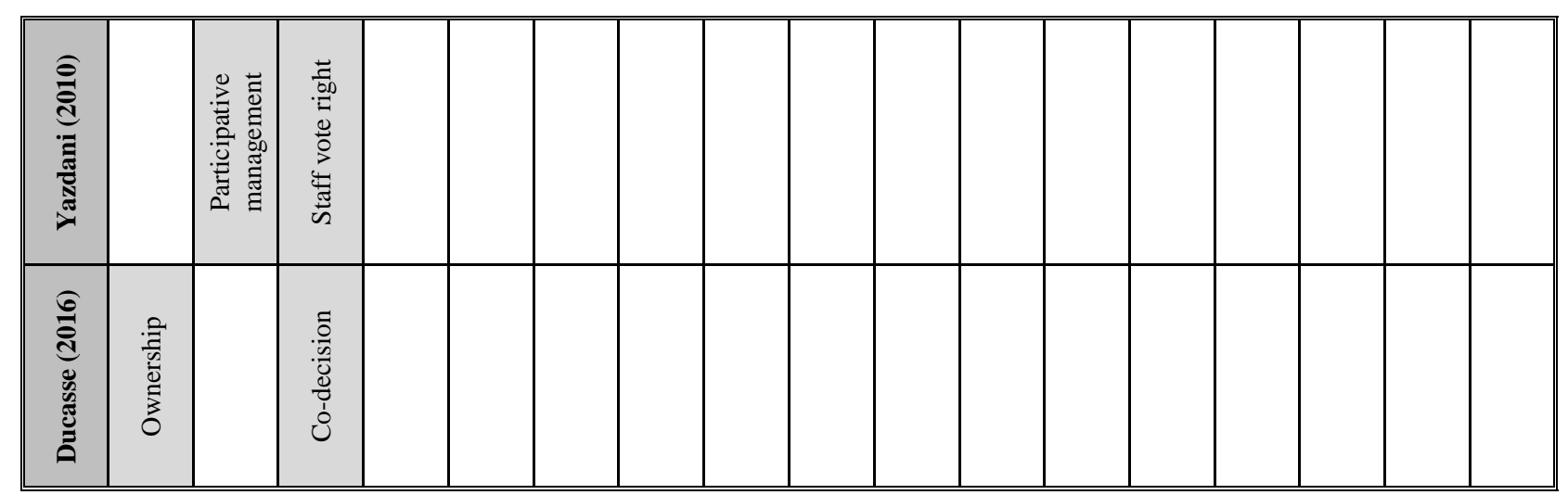




\begin{tabular}{|c|c|c|c|c|c|c|c|c|c|c|c|c|c|c|c|c|c|}
\hline 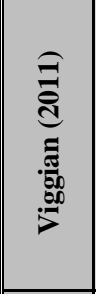 & 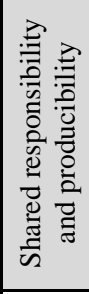 & 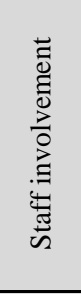 & 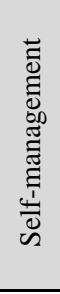 & 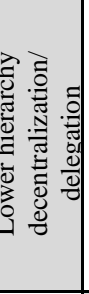 & & & & $\begin{array}{l}\overrightarrow{\mathrm{a}^{2}} \\
\vec{E}\end{array}$ & & & 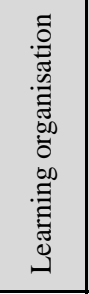 & 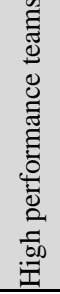 & & & & & \\
\hline 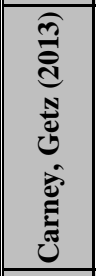 & & 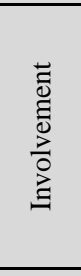 & & & 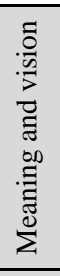 & & & & & & & & & & & & \\
\hline 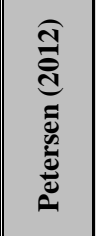 & 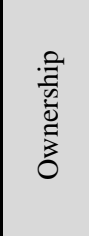 & 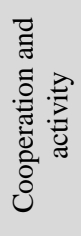 & 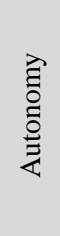 & 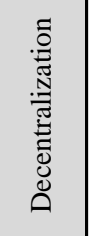 & 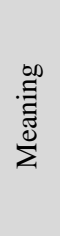 & 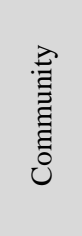 & 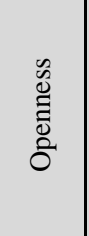 & $\stackrel{\overrightarrow{\mathrm{g}}}{\vec{E}}$ & & & 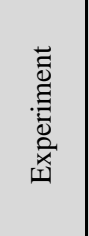 & $\begin{array}{l}\overrightarrow{0} \\
\mathbb{0} \\
\tilde{n}\end{array}$ & 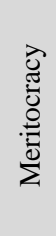 & 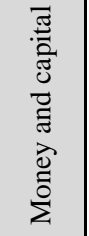 & & 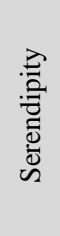 & 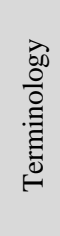 \\
\hline 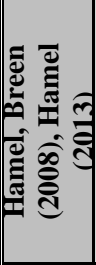 & 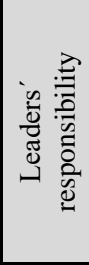 & 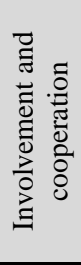 & & 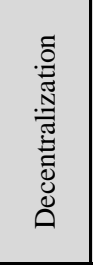 & 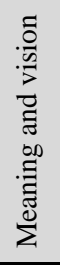 & 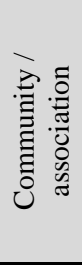 & 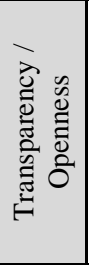 & & 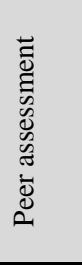 & & 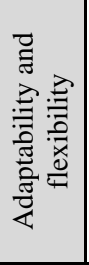 & & 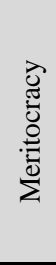 & 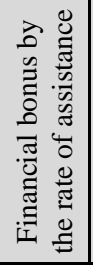 & 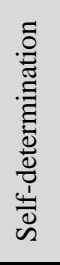 & & \\
\hline 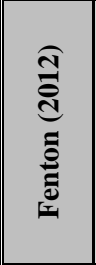 & 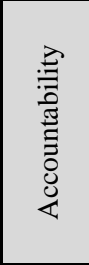 & 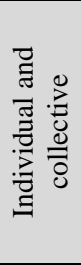 & $\begin{array}{l}\stackrel{\mathscr{O}}{0} \\
\frac{0}{U}\end{array}$ & 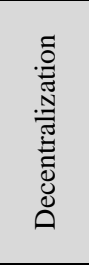 & 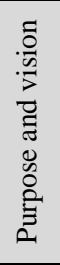 & 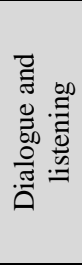 & 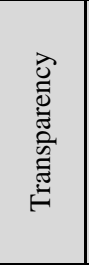 & 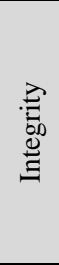 & 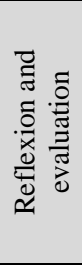 & 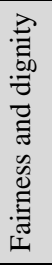 & & & & & & & \\
\hline
\end{tabular}

(Source: own processing, by Fenton, 2012: 61, Hamel, Breen, 2008: 155-156; Hamel, 2013: 174, Petersen, 2012, Carney, Getz, 2013, Viggian, 2011: 6-7, Ducasse, 2016: 32, Yazdani, 2010)

Each of the principles has mutual links and some of the principles could be considered as principles of the parent. When examining the principles, the authors of the research exhaled from the concept of Fenton (2012). Defined principles of the democratic companies can be understood differently and because of this, there is a description of each of the principles and their importance below. Some of the principles may be semantically mingled or to have reciprocal links.

\section{Meaning and vision}

Hajzler (2017) perceives this principle as "a setting the meaning of the company so that it is understandable and magnetic. Defining the vision in order to give direction to the organization and the people inside and around it". The meaning and the vision is a key principle for a democratic organization that determines whether an employee can go along with where the company is going and if he or she will be involved, or not and in this case, it will be more appropriate for him or her to work somewhere else. According to Slinták (2016) the profit or market value cannot be served as sufficient justification for the purpose of the organization.

\section{Dialogue and listening}

Fenton (2012) in this principle stresses that the discussions should be conducted so as to provide a new level of meaning, connections and ideas. To ensure that people are willing to say their views 
out loud, is needed them to be listened to. And it's not just about listening to subordinate by superiors, but listen for all to all.

\section{Fair play and honour}

This principle encompasses the idea of justice and equality. Although this principle was given only by Hajzler (2017) and Fenton (2012), the authors consider this principle as important. This does not mean that the newcomer will have the same powers as a long-time experienced staff, however each should be behaved with "fair play and honour" (Fenton, 2012).

\section{Transparency}

Transparency or openness of information in the company also means that "everyone shall have access to the information they need for independent decision making, including information about the financial results and business strategy" (Hajzler, 2017). It is also about the willingness of all the people in the company to share the information (Petersen, 2012). A prerequisite for this principle is "that people want to do things right, but to find out what is proper, they need a large amount of information." (Hamel, 2013: 244) And to ensure that the information they have, they need to be open. To ensure that the people in the company can work with the information; they need to understand them and know how to dispose of them (Hajzler, 2017).

\section{Responsibility}

The company with the responsibility creates an environment in which it is clear who is responsible to whom and for what, and, secondly, towards the inside of the company but also on the outside (Hajzler, 2017). Responsibility means that it is possible to rely on the person and do not need to control. Wilson (2011: 119) draws attention to the fact that the effective use of self-management strategies leads significantly to reduce the importance of the monitoring and controlling of employees.

Ducasse (2016: 32) understands the principle of responsibility not only as a responsibility to one to another, but also as a responsibility to the company. By this, Ducasse means that employees have to be co-owners, whether in the form of stock ownership, or in the form of bonuses.

But it is not only about the ownership from the perspective of finance. Harrison and Freeman (2004: 53) state that this is even a greater degree of ownership of the process and outputs of the organization.

\section{Involvement}

Schaufeli et al. (2002: 74) characterize involvement as "a positive, satisfying, work-related mental condition characterized by high levels of energy, dedication to work and enthusiasm." They further argue that involvement is a long-term status of mind that is not focused on a particular object, event, individual or behaviour.

With the principle of involvement is related to other concepts such as initiative, engagement, participation, and interest and proactivity. Yazdani (2010) as the two basic characteristics of the democratic organisation mentions the participatory management and provides more space for the opinion of the employees. The principle of the involvement, therefore, includes both the interests of the employees, but also an initiative to bring new impulses.

\section{Co-decision}

The co-decision procedure in the company means that the decision is not made only by superiors, but all may participate in the decision making. This is the freedom of employees to make decisions without the prior consent of senior management (Petersen, 2012). Hajzler (2017) explains the principle of co-decision as follows: "decision-making processes should be set up so that each 
member of the organization should have an opportunity to decide what to do, when, where, with whom and for how much."

\section{Integrity}

This is partly about setting up the life of the organization and individuals so that its actions are in accordance with ethical and moral principles (Hajzler, 2017, Fenton, 2012), but this is not just about the ethical and moral principles. It is also about trust that Petersen (2012) describes the trust as a faith in the fact that everyone within the team will behave with the best knowledge and conscience. The integrity of the company, therefore, refers to both the organization as a whole and to individual members of the organization.

\section{Decentralization}

Fenton (2012) talks about the power, which is distributed and shared across the organization. This is the approach where the decision-making right is not exercised in a hierarchical structure from the top downwards, but it is rather kept in smaller units throughout the organization (Petersen, 2012). The principle of decentralization is, therefore, closely related to the concept of "reduced hierarchy". Viggian (2011: 6) states that many theorists and practitioners indicate the reduced hierarchy of management as one of the elements of the democratic company.

\section{Reflexion and assessment}

In a democratic organization, there should be a culture of learning, and the constant desire to improve (Fenton, 2012: 61), this helps the reflection and evaluation. Hamel (2013: 174) stresses that this should be all about peer feedback, not the feedback from the top.

Each of the ten principles listed above has for the freedom-based management its relevance. Some of the principles are relevant more, some less, but how Fenton stresses (2012: 60) the real value in the organization these principles brings when they are practised all. Individual principles link other principles. It is possible to discern that some principles are for the others as key ones. A key principle is a principle that when an unsuccessful application will also affect the successful application of other principles.

\section{METHODOLOGICAL BASES}

Research on using case studies in the last 30 years has seen an extraordinary increase in socialscientific research, including research on business and management (Dul, Hak, 2008). One of the important issues in a methodology for the case studies includes the size of the research sample. It is usually assumed that there is no ideal number of cases and that the number between four and ten usually provides good results. Research which is carried out using case studies does not aspire on compliance with the requirement of the representativeness of the sample (Štrach, 2007). The multiple-case design method has been applied. In the case of multiple-case designs, it is important to monitor the replication logic rather than sampling logic. Individual case studies are perceived in a manner similar to multiple experiments (Yin, 1994).

The research was carried out in the period March-April 2017. Data collection was conducted using a questionnaire survey and using the interview with the heads and leaders of the companies. The questionnaire was carried out and recorded using docs.google. The evaluation of the questionnaire was carried out in the program IBM SPPS Statistics 22 (frequency, median) and in Microsoft Excel (donvar). Interviews were recorded in the forms of audio and then transliterated.

The research sample was selected using the methods of "snowball". As the first company was chosen the company of Raynet, at the meeting with Raynet were recommended the other companies 
- Court of Moravia, Na stejné lodi and the company of Impact Hub. The last company - Bidding

Tools was selected due to the contact search on Impact Hub, which ultimately was not selected.

In addition to the semi-structured interviews and questionnaires were used for research, also other resources: Web sites the companies investigated, media interview from the site, internal documents and observations in participating in the consultation. The following Table 2 summarizes which methods were applied in the individual companies.

\section{Table 2 Applied methods in the companies}

\begin{tabular}{||l|c|c|c|c||}
\hline \hline METHOD & RAYNET & $\begin{array}{l}\text { COURT OF } \\
\text { MORAVIA }\end{array}$ & BIDDING TOLLS & NA STEJNÉ LODI \\
\hline Interview & $\checkmark$ & $\checkmark$ & $\checkmark$ & $\checkmark$ \\
\hline Questionnaire & $\checkmark$ & $\checkmark$ & $\checkmark$ & $\checkmark$ \\
\hline Websites & $\checkmark$ & $\checkmark$ & $\checkmark$ & $\mathrm{x}$ \\
\hline Website interview & $\checkmark$ & $\mathrm{x}$ & $\checkmark$ & $\mathrm{x}$ \\
\hline Internal documents & $\checkmark$ & $\mathrm{x}$ & $\mathrm{x}$ & \\
\hline
\end{tabular}

(Source: own processing)

The interviews were conducted with managers or statutories of the companies, and the interview was conducted using the premade themes which the researcher followed from the part. The interviews were focused on a brief introduction of the company, the introduction of the freedom of work, principles of freedom-based management, the advantages and disadvantages of the procedure, the appropriateness of freedom-based management for other companies, and recommendations for further research. In this article, there are evaluated the responses of block-oriented in principles of management.

The questionnaire was carried out using a Web form www.docs.google.com. The questionnaire was inspired by Hajzler's (2017) questionnaire that contains questions related to the principles of the democratic companies. Hajzler (ibid) applies this questionnaire to measure the application of the principles in organizations. The questionnaire contained two main parts: the application of the principles of freedom-based management and the importance of the principles of freedom-based management. Each part has 35 questions. The questions were divided according to the principles of freedom-based management.

Some of the principles were represented by four questions and the other for example, only two. In the first part, the respondents were asked to rate how much do they agree with the following statements, and in the second part, they were asked to rate the extent to which the values are defined by using the phrases important to them. In both cases the assessments were conducted on a scale from 1 to 5, with each value was defined such as verbally ,very agree," " even disagree, or agree", etc.

The poll was carried out in four companies for which was the assumption that they have free management - Raynet, Court of Moravia, Bidding Tools, and Na stejné lodi. Table 3 summarizes the basic information concerning the companies. The questionnaire was sent by managers; therefore it is not possible to evaluate the rate of return. The research of the sample survey was counted the answers of all the people, for a total of 31 responses. Representation of respondents from different companies is not uniform. Questionnaire was filled in by 12 men and 19 women. Bidding Tools 11 respondents, in the case of Court of Moravia - 9 respondents, 6 respondents were from the company of Raynet and 5 people from Na stejné lodi. 
Table 3 Key data of the companies

\begin{tabular}{||l|c|c|c|c||}
\hline \hline & RAYNET & $\begin{array}{c}\text { COURT OF } \\
\text { MORAVIA }\end{array}$ & BIDDING TOOLS & NA STEJNÉ LODI \\
\hline $\begin{array}{l}\text { Respondent in the } \\
\text { interview }\end{array}$ & Martin Bazala & Petr Pouchlý & $\begin{array}{c}\text { Rostislav } \\
\text { Urbánek }\end{array}$ & $\begin{array}{c}\text { Martin Tyšer, } \\
\text { Tomáš } \\
\text { Buchwaldek }\end{array}$ \\
\hline Based in & Ostrava & Brno & Ostrava & Ostrava \\
\hline Lifetime in years & 12 & 4 & 3 & 2 \\
\hline $\begin{array}{l}\text { Staff number in a } \\
\text { team }\end{array}$ & 20 & $15-20$ & $25-30$ & 12 \\
\hline $\begin{array}{l}\text { Democratic } \\
\text { organisation since } \\
\text { establishment }\end{array}$ & $\mathrm{x}$ & $\checkmark$ & $\checkmark$ & $\checkmark$ \\
\hline
\end{tabular}

(Source: own processing)

\section{DESCRIPTION OF THE CASES}

Raynet, s.r.o.

Raynet is one of the most successful software companies dealing with cloud-based CRM. Twelve years ago, it was founded largely by students in the traditional way. After six years, the company was transformed into a democratic company. The largest number of employees in the history of the Raynet was about thirty-five employees; currently it has about 20 employees.

\section{Court of Moravia, s.r.o.}

Court of Moravia deals with the so-called playful design and gamification. This group of people first existed as a group of friends, and then a non-profit organization that conducted the experiential games and training in various areas. Four years ago, the company started as a legal firm. Currently, the number of employees varies between 15 and 20, while some workers are part-time only, for example due to parent leaves.

BiddingTools Group, s.r.o.

Bidding Tools was established three years ago. At the beginning, there was a group of people created the exact projects to automate the process of bidding. The company currently has about twelve to fifteen employees at full-time contracts and almost the same number of part-time workers and trainees. The team consists of a total of about twenty-five to thirty people.

\section{Nastejnelodi.cz, s.r.o.}

$\mathrm{Na}$ stejné lodi is the accounting firm that focuses on accounting, tax optimization and use of accounting data for strategic purposes. The company officially began two years ago; however, it has been in process for four years. The current number of employees is twelve persons.

\section{RESULTS}

\subsection{Questionnaire}


The highest ordinal dispersion (dorvar) in examining the application of the principles has been identified in statements aimed at access to information about the financial results of the company (n. 10, Transparency, dorvar 1.503), on the ability to affect the amount of own financial evaluation (n. 25, Co-decision, dorvar 1.357) and the existence of tools providing feedback (n. 35, Reflection and assessment, dorvar 1.303). In contrast, the lowest ordinal dispersion has been reported for claims focused on the ability to come up with an idea which others will be heard (n. 6, Dialogue and listening, dorvar 0.062). All claims relating to the principle of "dialogue and listening" have the lowest median 5 and dorvar. The only item with a median 3 had the claim concerning the possibility of agreeing, for how much money the employee will work (n. 25). Five claims have reached a median of 4 (two of them relating to the principle of decentralization and two "reflection and assessment").

In evaluating the importance of the principles have been recorded minor differences between ordinals variances, no claim of median reached lower than 4.

In the case of individual companies, the median is less than 3 has been observed in reviews the application of the access to the financial results of the company (median 2, company Bidding Tools).

Table 4 Principles of workplace democracy - results from questionnaires

\begin{tabular}{|c|c|c|c|c|c|c|}
\hline N. & Principle & Question & 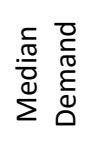 & 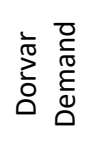 & 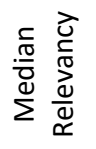 & 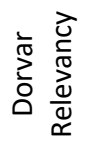 \\
\hline 1 & \multirow{2}{*}{$\begin{array}{l}\text { Meaning and } \\
\text { vision }\end{array}$} & $\begin{array}{l}\text { The Mission of our company (why does it exist) is for people in our } \\
\text { company really attractive. }\end{array}$ & 5 & 0,583 & 4 & 0,685 \\
\hline 2 & & $\begin{array}{l}\text { Defined vision (what we want to achieve in your company) gives our } \\
\text { company direction. }\end{array}$ & 5 & 0,783 & 5 & 0,791 \\
\hline 3 & \multirow{4}{*}{$\begin{array}{l}\text { Dialogue and } \\
\text { listening }\end{array}$} & $\begin{array}{l}\text { Our company actively creates opportunities for open discussion of all } \\
\text { the people in the company. }\end{array}$ & 5 & 0,225 & 5 & 0,643 \\
\hline 4 & & $\begin{array}{l}\text { Most of the people in our company can actively listen to others with a } \\
\text { goal to reach an agreement. }\end{array}$ & 5 & 0,375 & 5 & 0,444 \\
\hline 5 & & $\begin{array}{l}\text { Our company is actively creating opportunities for dialogue with } \\
\text { customers, suppliers and others. }\end{array}$ & 5 & 0,437 & 4 & 0,867 \\
\hline 6 & & $\begin{array}{l}\text { People in our company can come up with any idea (suggestion, idea, } \\
\text { problem, solution, disapproval) and others will listen to it. }\end{array}$ & 5 & 0,062 & 5 & 0,337 \\
\hline 7 & \multirow{2}{*}{$\begin{array}{c}\text { Fair play and } \\
\text { honour }\end{array}$} & $\begin{array}{l}\text { People in our company are not dividing to "child" and "parent". There } \\
\text { is a prevailing feeling that we are equal. }\end{array}$ & 5 & 0,549 & 4 & 0,87 \\
\hline 8 & & $\begin{array}{l}\text { Both financial and non-financial rewards in our company are } \\
\text { distributed fairly. }\end{array}$ & 5 & 1,040 & 5 & 0,623 \\
\hline 9 & \multirow{5}{*}{ Transparency } & $\begin{array}{l}\text { All the people in our company have access to the information they } \\
\text { need for independent decision making. }\end{array}$ & 5 & 0,499 & 5 & 0,293 \\
\hline 10 & & $\begin{array}{l}\text { All the people in our company have access to information about the } \\
\text { financial results of the company. }\end{array}$ & 5 & 1,503 & 4 & 0,798 \\
\hline 11 & & $\begin{array}{l}\text { All the people in our company have access to information about the } \\
\text { strategy of the company. }\end{array}$ & 5 & 0,475 & 4 & 0,681 \\
\hline 12 & & $\begin{array}{l}\text { People in our company understand information about our company } \\
\text { (about strategy, about the results of the procedures, etc.) and can } \\
\text { deal with them. }\end{array}$ & 5 & 0,724 & 5 & 0,630 \\
\hline 13 & & The operation of our company is transparent to our customers. & 4 & 0,970 & 4 & 0,944 \\
\hline 14 & \multirow{3}{*}{ Responsibility } & $\begin{array}{l}\text { Our company develops the principle of personal responsibility of the } \\
\text { employees. }\end{array}$ & 5 & 0,466 & 5 & 0,559 \\
\hline 15 & & People in our company know who is responsible for what. & 5 & 0,837 & 5 & 0,346 \\
\hline 16 & & Our company is built on ethical principles. & 5 & 0,620 & 5 & 0,837 \\
\hline 17 & \multirow{2}{*}{ Involvement } & In our company there is a sense of belonging to the company. & 5 & 0,774 & 5 & 0,615 \\
\hline 18 & & The emphasis on unity is in balance with the company focusing on the & 5 & 0,737 & 5 & 0,508 \\
\hline
\end{tabular}




\begin{tabular}{|c|c|c|c|c|c|c|}
\hline & & own identity of every person in our company. & & & & \\
\hline 19 & & $\begin{array}{l}\text { People in our company are willing to work even beyond the scope of } \\
\text { their duties. }\end{array}$ & 5 & 0,620 & 4 & 0,903 \\
\hline 20 & & $\begin{array}{l}\text { People in our company are coming up with ideas by themselves and } \\
\text { are willing to implement them. }\end{array}$ & 5 & 0,579 & 5 & 0,546 \\
\hline 21 & \multirow{5}{*}{ Co-decision } & People in our company can agree on what they will do. & 5 & 0,695 & 4,5 & 0,569 \\
\hline 22 & & People in our company can agree on where and when they will work & 5 & 0,653 & 5 & 0,638 \\
\hline 23 & & People in our company can agree on with whom will they work. & 5 & 1,024 & 4 & 0,622 \\
\hline 24 & & People in our company may agree on how they will work. & 5 & 0,612 & 5 & 0,681 \\
\hline 25 & & People in our company can agree on for how much they will work. & 3 & 1,357 & 4 & 0,827 \\
\hline 26 & \multirow[b]{2}{*}{ Integrity } & What our company is doing is in accordance with what it says. & 5 & 0,88 & 5 & 0,362 \\
\hline 27 & & $\begin{array}{l}\text { In our company there is mutual confidence from management and } \\
\text { employees. }\end{array}$ & 5 & 0,566 & 5 & 0,293 \\
\hline 28 & \multirow{4}{*}{ Decentralization } & People in our team decide on most of what they do on their own. & 4 & 0,724 & 5 & 0,783 \\
\hline 29 & & $\begin{array}{l}\text { Knowledge and power in our company are spread out, rather than } \\
\text { concentrated in one place. }\end{array}$ & 5 & 0,787 & 4 & 0,860 \\
\hline 30 & & $\begin{array}{l}\text { People in our company communicate directly-communication } \\
\text { channels don't go through a middleman. }\end{array}$ & 5 & 0,658 & 5 & 0,793 \\
\hline 31 & & $\begin{array}{l}\text { If the management of our company received a "blow to the head", the } \\
\text { company will continue to operate. }\end{array}$ & 4 & 0,912 & 4 & 0,630 \\
\hline 32 & \multirow{4}{*}{$\begin{array}{l}\text { Reflexion and } \\
\text { assessment }\end{array}$} & People in our company have plenty of feedback. & 4 & 0,857 & 5 & 0,490 \\
\hline 33 & & At our company feedback is primarily constructive. & 5 & 0,537 & 5 & 0,569 \\
\hline 34 & & People in our company understand the importance of feedback. & 5 & 0,644 & 5 & 0,566 \\
\hline 35 & & $\begin{array}{l}\text { In our company we have tools that help us get feedback (e.g. } \\
\text { questionnaires, moderated meetings, scoreboard, ...) }\end{array}$ & 4 & 1,303 & 4 & 0,867 \\
\hline
\end{tabular}

(Source: own processing)

\subsection{Interviews}

Principles listed below were expressed in interviews, however, many of the companies have not been explicitly mentioned when querying for the principles of workplace democracy, but in other parts of the interviews. If the principle applied in the company, the check box is marked " $\checkmark "$. If the principle clearly does not apply, the check box is marked "x". If it is not possible to determine whether it can be applied, the check box is marked with "?". If the principle is applied only partially, the check box is marked with "+/-".

Majority of the principles of management identified in the interviews agree with the principles stated in the theoretical findings. The most important appear to be openness, accountability, transparency, and regular meetings, which is a tool for effective dialogue and listening.

\section{Table 5 Comparison of below mentioned principles of workplace democracy}

\begin{tabular}{||l|c|c|c|c||}
\hline \multicolumn{1}{|c|}{ PRINCIPLE } & RAYNET & $\begin{array}{c}\text { COURT OF } \\
\text { MORAVIA }\end{array}$ & BIDDING TOLLS & NA STEJNÉ LODI \\
\hline Openness \& trust & $\checkmark$ & $\checkmark$ & $\checkmark$ & $\checkmark$ \\
\hline Responsibility & $\checkmark$ & $\checkmark$ & $\checkmark$ & $\checkmark$ \\
\hline Honour and fair play & $\checkmark$ & $\checkmark$ & $\checkmark$ & $\checkmark$ \\
\hline Roles of the leaders & $\checkmark$ & $\checkmark$ & $\mathrm{x}$ & $\checkmark$ \\
\hline Self-management & $\checkmark$ & $\checkmark$ & $\mathrm{x}$ & $\checkmark$ \\
\hline Organizational structure & $\checkmark$ & $\checkmark$ & $\mathrm{x}$ & $\checkmark$ \\
\hline Transparent accounting & $\checkmark$ & $\checkmark$ & $\mathrm{x}$ & $\checkmark$ \\
\hline Transparent payments & $\checkmark$ & $\checkmark$ & $\checkmark$ & $\checkmark$ \\
\hline Profit sharing & $\checkmark$ & & & $\checkmark$ \\
\hline \hline
\end{tabular}




\begin{tabular}{||l|c|c|c|c||}
\hline Career prospects & $\checkmark$ & $+/-$ & $\checkmark$ & $\checkmark$ \\
\hline Long-time sustainability & $?$ & $?$ & $?$ & $\checkmark$ \\
\hline
\end{tabular}

(Source: own processing)

\section{Responsibility}

The surveyed democratic companies give employees more freedom; however, they require a high degree of responsibility, which is the key to the effective functioning of democratic companies. A company's values document $\mathrm{Na}$ stejné lodi describes the concept of responsibility as "always do $100 \%$ to meet the promises that we have made." If there are people who are trainees and do not yet have a sufficient level of responsibility, is not given such a degree of freedom. It is possible to say that the degree of freedom is proportional to the degree of responsibility of the employee.

Leader from Bidding Tools: ,, When they become temporary workers, they can have some freedom and it is again a gradual process. In people, where we find that they are able to take responsibility and get some freedom, we gradually give it to them."

\section{Roles of the leaders}

An important value is also an example of leaders and honesty and fairness. It is necessary to corporate leaders to do what they demand from the others and so that they would be the example.

Leader from Bidding Tools: „If I hear people say 'do the best, do the best 'and come here at 10am and at 2pm I go home, it probably won't work. But when people see me in the morning, they see that I'm staying here late and on weekends I'm sending emails, so it is again another thing. “

Leaders are also important in the implementation of freedom into the organization. Carney, Getz (2013: 93) states that "change must begin from the leader himself." It is not possible to establish freedom from below.

Leader from Court of Moravia: ,, The first thing is to say, if that's what we want to do. The organization must decide that it wants to do it. Ideally its leadership. If not, the bottom turns horribly wrong. (...) It has to come from the head. It does not happen from the bottom."

The roles of leaders in the democratic companies vary from the traditional way of management by leaders trying to give support to the less experienced, not to manage them. The aim is that each man was able to control the majority of his/her work.

Leader from Bidding Tools: ,, The primary role of a leader is not to be a parent, but to help a man in his personal growth and move it forward."

\section{Organizational structure}

Hierarchy of the democratic companies surveyed is very flat. The organizational structure of these companies is more circular than the pyramid. This is the exact "amoebas" (departments such as design, business, and support) that can intermingle. In many cases, the organizational structure is not directly written down, but still, everybody knows who is responsible for what. If this is a project management, in the framework of the projects there are responsible persons for a given project. People in the company do not have official titles, but the team knows who are the "experienced ones". 


\section{Intrapreneurship}

Freedom-based management is trying to make the staff entrepreneurs inside the company - to manage themselves, work with responsibility, with risk, with finance, with profit and loss.

Leader from Raynet: „,People in the company are partially leaving the employee's position and getting into the position of the entrepreneur. The more people are 'the firm', the more they start to have fun and have a greater involvement."

\section{Transparent economics}

In order for people to be intrapreneurial individuals, it is necessary to provide them enough information. This is for example, to have opportunity to look at the financial statements of the company. The surveyed companies provide their employees with spreadsheets, reports and statistics on the economic situation of the companies that support the motivation of employees, because they see what effect their work has, or can have. This transparency is also leading to fair play of the staff, as each activity is obvious and can be seen by anyone.

Leader from Court of Moravia: „, The fact that each crown is traceable, there is no risk that someone would take away something. “

A part of the open economics is open salaries. In Bidding Tools are in this area, however, in the early days and they did not set it.

Leader from Bidding Tools: „, The only thing where I'm not sure if we will one day show transparently to everyone who gets how much money. So far, it is not so."

\section{Staff salaries}

The company indicate the different systems of the financial remuneration and each company worth its own system. Probably there is no one universal model reviews for democratic companies, but it is more of an individual matter dependent on the nature of the business.

Raynet and Bidding Tools have flat monthly salaries. In the Court of Moravia, people are rewarded by the hours worked, which they shall report and evaluation also depends on the type of project. Trust and honesty of people in a democratic company is necessary, because the employees themselves show the number of hours worked and no one checks whether it is reported correctly, even though it would be possible to trace.

Leader from Court of Moravia: „For all the time that we have not had any case that someone has abused. On the contrary, I solved the opposite problem that guys have spent more time on it than reported, and they thought it's stupid to report so many hours, because they thought that they could have done it more efficiently. "

In contrast with an hourly salary in the Court of Moravia, in Na stejné lodi, they feel that hourly salary is the "anachronism of communism and killing innovation." In Na stejné lodi the reward is set up in the employee contract as part of the fixed part but in fact it is a majority of the variable part.

\section{Profit sharing}

The common practice of the surveyed democratic companies is the involvement of their employees to profit distributions. A specific system for allocating profit in the companies differs. The employees divide a certain part of the employees profit by using mutual dialogue and the codecision procedure, which is a condition that came to the consent of all involved.

Leaders from Na stejné lodi: „, They have only one condition, that all must agree. If one does not agree, then we will decide. “ 
Employees in Raynet can distribute the profit only at the stage of "Staging", "Stable" and "Partner". Raynet employees divide only a quarter of profit, the rest is divided among the owners, business and charitable purposes.

\begin{abstract}
Meetings
Difference of openness in democratic businesses is supported by regular meetings. In the company of Raynet also exists in the rule that anyone from the company may participate in any meeting that interests him. This does not mean that anyone could talk to anything, but it means that any employee may hear what is discussed at the meetings and can know what's happening. The investigated companies have essentially a very flexible working time, however, one of the few things which are required, is to be part of the joint meetings.
\end{abstract}

\title{
CONCLUSIONS AND IMPLICATIONS
}

Ducasse (2013: 32) claims that the freedom-based management can bring higher profits and greater productivity of the company. The research, however, does not explicitly claim this. Whether the freedom-based management is in the right direction in the area of management in the 21 st century, it might be possible to evaluate in a few years. The authors recommend to be carried out comparative research in the area of profitability of democratic and traditional companies. In this research, it will be needed to carefully choose the company with traditional and freedom-based proceedings which involved into the category of similar in terms of size, product, and other benchmarks.

It is recommended to do qualitative research barriers for implementation of corporate freedom. It would be a research that should reveal the reasons for the fear of the introduction of this model. In addition to the barriers it is also recommended to determine whether people are interested in a freedom-based way to manage people (employees and managers), and if so, to what extent.

Furthermore, it is recommended to execute the questionnaire survey in companies with traditional management and subsequently compare 1) whether the principles of democratic companies are for employees of traditional companies important and how much and 2) whether the application of the principles of democracy in companies with traditional management is lower than for firms with the freedom-based management. If it turned out that even people in companies with traditional management long for application of the principles of freedom in their work, it would be appropriate to consider the introduction of workplace democracy to more companies.

The recommendation is also to perform longer-term research of selected companies and survey on them the development of their application of freedom-based management. This may be the companies that are managed traditionally, but they plan to transform into the democratic company, but also democratic business to observe, what long-term effect does the freedom-based management has on them.

The research has certain restrictions, which are for example: a small research sample and a short history of the companies surveyed. The research reaches the four companies, while the questionnaire was replied on average by seven people. Therefore, it is necessary to mention that this research is a good beginning of research in the field of freedom-based management, but for the wider practice, it is necessary to extend and focus the research on other directions. The analyzed companies are rather less-sized companies. From this perspective, it would be appropriate to implement research in larger companies. The subjects have a short corporate history and many of them are in the early stages of the application of workplace democracy. It is therefore not yet possible to conclusively point to the success of these examples. For further research, it is 
recommended to be executed a renewed research in these companies for a number following years, which confirms the validity of the recorded facts.

\section{REFERENCES}

Bernstein, E., Bunch, J., Canner, N., Lee, M. (2016) Beyond the holacracy hype. Harvard Business Review, vol. 94, no. 7/8, pp. 38-49.

Birkinshaw, J. (2014) Beware the next big thing. Harvard Business Review, vol. 92, no. 5, pp. 5057.

Boes, A., Sattelberger, T., Welpe, I. M. (2015) Digitalization facilitates greater employee participation - but can also mean more control. TUMstudinews. The Newsletter for student of TUM, Issue 4. Available from <https://www.tum.de/en/studies/studinews/issue042015/show/article/32094/> Consulted: 1. 2. 2017.

Brafman, O., Beckstrom, R. A. (2006) The Starfish and the Spider: the Unstoppable power of Leaderless Organizations. New York: Portfolio. ISBN 9781591841432.

Carney, B. M., Getz, I. (2013) Svoboda v práci: jak nechat zaměstnance dělat, co chtějí, a tím zvýšit produktivitu, zisk a růst. Praha: PeopleComm. ISBN 978-80-904890-7-3.

Ducasse, P. (2016) Democracy at Work: Happier and More Productive Workplaces Are Within Reach, CCPA Monitor, vol. 22, no. 5, pp. 32-33.

Dul, J., Hak, T. (2008) Case Study Methodology in Business Research. Oxford: ButterworthHeinemann. ISBN: 978-0-7506-8196-4.

Fenton, T. L. (2006) Democracy in the Workplace. Inside Tucson Business, vol. 16, no. 11, pp. 6.

Fenton, T. L. (2012) Inspiring Democracy in the Workplace: From Fear-based to Freedom-centered Organizations, Leader To Leader, no. 64, pp. 57-63.

Getz, I. (2009) Liberating Leadership: How the Initiative-Freeing Radical Organizational Form Has Been Successfully Adopted. California Management Review, vol. 51, no. 4, pp. 31-58.

Gratton, L. (2004) The Democratic Enterprise. Harlow: Pearson Education Limited. ISBN: 0-27367528-1.

Hajzler, T. (2017) Svobodná a zodpovědná firma: Jak pře/vy-budovat firmu na principech svobody a zodpovědnosti. Available from www: <https://www.tomashajzler.com/tema/svobodnafirma> Consulted: 1. 2. 2017.

Hamel, G. (2013) Na čem dnes záleži: jak vyhrát ve světě neustálých změn, dravé konkurence a nezastavitelné inovace. Praha: PeopleComm. ISBN 978-80-904890-6-6.

Hamel, G., Breen, B. (2008) Budoucnost managementu. Praha: Management Press. ISBN 978-807261-188-1.

Handy, Ch. (2015) The Second Curve: Thoughts on Reinventing Society. London: Random House. ISBN-10: 1847941346.

Harrison, J. S., Freeman, R. E. (2004) Special Topic - Democracy in and Around Organizations. Academy of Management Executive, vol. 18, no. 3, pp. 49-53.

Hsieh, T. (2013) Štěstí doručeno: pohled do budoucnosti firem, které vytvářeji štěstí, pak peníze. Praha: PeopleComm. ISBN 978-80-87917-05-3.

Kejhová, H. (2015) Spolupodnikání ve firmě: tahounů je málo. Moderní ř́zení, vol. 50, no. 3, pp. 28-29.

Laloux, F. (2014) Reinventing Organizations. Brussels: Nelson Parker. ISBN-10: 2960133501.

Maravelias, Ch. (2007) Freedom at Work in the Age of Postbureaucratic Organization. Ephemera: Theory \& Politics in Organization, vol. 7, no. 4, pp. 555-574.

McAuley, J., Duberley, J., Johnson, P. (2006) Organization Theory: Challenges and Perspectives. Harlow: Prentice Hall. ISBN-10: 0273687743.

Petersen, C. J. (2012) Mixing it Up. Available from www <https://christianjakobsenpetersen.wordpress.com/tag/management-2-0-principles/>. Consulted: 28. 2. 2017. 
Pfeffer, J. (2013) You're Still the Same: Why Theories of Power Hold over Time and across Contexts. Academy of Management Perspectives, vol. 27, no. 4, pp. 269-280.

Proenca, T. (2010) Self-Managed Work Teams: An Enabling or Coercive Nature. International Journal of Human Resource Management, vol. 21, no. 3, pp. 337-354.

Reingold, J. (2016) The Zappos Experiment. Fortune, vol. 173, no. 4, pp. 206-214.

Robertson, B. J. (2015) Holacracy: The New Management System for a Rapidly Changing World. New York: Henry Holt and Co. ISBN 978-1-62779-428-2.

Schaufeli, W. B., Salanova, M., González-Romá, V., Bakker, A. B. (2002) The Measurement of Engagement and Burnout: a Two Sample Confirmatory Factor Analytic Approach. Journal of Happiness Studies, vol. 3, no. 1, pp. 71-92.

Semler, R. (2011) Podivín: přiběh nejneobvyklejšiho pracoviště světa. Praha: PeopleComm. ISBN 978-80-904890-0-4.

Senge, P. M. (2006) The Fifth Discipline: The art and practice of the learning organization: Second edition. London: Random House. ISBN-10: 1905211201.

Slinták, K. (2015) Cultural reversal: Why does obedience lose with the initiative? International Journal of Entrepreneurial Knowledge, vol. 3, no. 2, pp. 59-75.

Slinták, K. (2016) Proces formování poslání na základě hlubšího pochopení firemního účelu. Scientific Papers of the University of Pardubice. Series D, Faculty of Economics \& Administration, vol. 23, issue 38, pp. 129-141.

Slinták, K., Tučková, Z. (2016) Citizen corporation as a form of social enterprise. Economic Annals-XXI, 162, 11/12, pp. 62-67.

Štrach, P. (2007) Tvorba výukových a výzkumných př́ípadových studií. Acta Oeconomica Pragensia, vol. 15, no. 3, pp. 22-36.

Useem, J. (2015) Are bosses necessary? Atlantic, vol. 316, no. 3, pp. 28-32.

Verdorfer, A. P., Weber, W. G. (2016) Examining the link between organizational democracy and employees' moral development. Journal of Moral Education, vol. 45 , no. 1, pp. 59-73.

Viggain, F. A. (2011) Phoenix Trucking - „I believe in Democracy Up to a Point“: Democratizing Management Hierarchies. International Journal of Management and Innovation, vol. 3, no. 1, pp. 1-31.

Weber, W., Unterrainer, C., Schmid, B. (2009) The influence of organizational democracy on employees' socio-moral climate and prosocial behavioral orientations. Journal of Organizational Behavior, vol. 30, no. 8, pp. 1127-1149.

Wilson, J. H. (2011) Freedom at Work: Psychological Empowerment and Self-Leadership. International Journal of Business and Public Administration, vol. 8, no. 1, pp. 106-124.

Yazdani, N. (2010) Organizational Democracy and Organization Structure Link: Role of Strategic Leadership \& Environmental Uncertainty, IBA Business Review, vol. 5, no. 2, pp. 51-74.

Yin, R. K. (1994), Case study research. Design and methods. 2nd edition, Vol. 5, London: SAGE Publications. 